ARKADIUSZ JASIŃSKI (D) orcid.org/0000-0002-5200-1174

Instytut Psychologii, Uniwersytet Opolski Institute of Psychology, University of Opole arkadiusz.jasinski@uni.opole.pl

ROMUALD DERBIS D orcid.org/0000-0001-5145-7922

Instytut Psychologii, Uniwersytet Opolski Institute of Psychology, University of Opole

ANNA OLESZKOWICZ iD orcid.org/0000-0002-8982-2953

ALEKSANDRA SŁOWIŃSKA (D) orcid.org/0000-0002-9498-501X

Instytut Psychologii, Uniwersytet Wrocławski Institute of Psychology, Wroclaw University

\title{
Postawy wobec globalizacji a satysfakcja z życia. Mediacyjna rola procesów tożsamościowych ${ }^{1}$
}

\author{
Attitudes toward Globalization and Life Satisfaction. \\ The Mediating Role of Identity Formation
}

\begin{abstract}
The aim of the research was to describe the relationship between attitudes toward globalization and life satisfaction and identity processes in the group of young adults. The sample included of 403 people at the age of $19-35(\mathrm{M}=22.84$, SD $=2.81), 219$ women $(54.3 \%)$ and 184 men. The relations were measured with the use of three questionnaires: Questionnaire of Attitudes Toward Globalization (Senejko, Łoś, 2016), Questionnaire of Identity Formation by A. Oleszkowicz, A. Słowińska (referring to the Dual-Cycle Model of Identity Formation by Luyckx et al., 2006) and SWLS Questionnaire (Diener et. al., 1985). Data analysis was based on structural equation modeling. The research results indicate a lack of direct relationship between attitudes toward globalization and life satisfaction. It was established that all of the identity processes differentiate the level of life satisfaction. The most powerful predictor of life satisfaction is a reflective exploration in depth. In the relation of attitudes toward globalization - life satisfaction, identity processes are mediators. The anxiety attitude toward globalization is in strong relationship with ruminative exploration processes. Critical attitude is in relationship with reflective exploration in breadth and depth and identification with commitment. The accepting attitude is in relationship with a reflective exploration in breadth and depth.
\end{abstract}

Keywords: attitudes toward globalization, life satisfaction, identity formation, young adults

Słowa kluczowe: postawy wobec globalizacji, satysfakcja z życia, procesy tożsamościowe, młodzi dorośli 


\section{WPROWADZENIE}

Rozwój psychologii pozytywnej postawił przed badaczami nowe wyzwania. Od lat 90. ubiegłego stulecia szybko rozwijającym się obszarem badań psychologicznych stała się problematyka dobrego życia, subiektywnego dobrostanu i szczęścia. Chociaż samo pojęcie psychologii pozytywnej zostało użyte po raz pierwszy i znacznie wcześniej przez Abrahama Maslowa, to istotne poszerzenie wiedzy o pozytywnych stronach życia, ich psychospołecznych uwarunkowaniach i konsekwencjach wiąże się z takimi twórcami tego kierunku, jak: Martin Seligman, Ed Diener, Charles Snyder czy Mihaly Csikszentmihalyi (Trzebińska, 2008).

Dotychczasowe badania pokazują, że jednoznaczna definicja satysfakcji z życia może być trudna do ustalenia i budzi pewne kontrowersje teoretyczne (Kowalik, 1995; Świerżewska, 2010). W naszej pracy odwołujemy się do rozumienia satysfakcji z życia w ujęciu Dienera i jego współpracowników, gdzie stanowi ona jeden z trzech elementów (filarów) subiektywnego dobrego samopoczucia. Dwa z nich to emocje pozytywne oraz brak lub niski poziom emocji negatywnych i wszelkich dolegliwości. Natomiast satysfakcja z życia (inaczej: zadowolenie z życia) jest wynikiem oceny poznawczej polegającej na porównaniu własnej sytuacji z przyjętymi kryteriami czy standardami. To, na ile osoba jest zadowolona z życia, zależy od stopnia osiągnięcia tychże standardów (Diener, Emmons, Larson, Griffin, 1985; Diener, Lucas, Oishi, 2002). Tym samym tak rozumiana satysfakcja z życia ma wymiar subiektywny i globalny, tzn. dotyczy życia w ogólnym ujęciu.

Dotychczasowe badania nad uwarunkowaniami subiektywnego dobrostanu pozwoliły zidentyfikować wiele czynników leżących u podstaw dobrego życia. Obok właściwości psychicznych, takich jak: duchowość, mądrość, poczucie sensu, nadzieja, poczucie własnej skuteczności i kontroli itp., wymienia się również czynniki społeczne, np. bliskie związki, ciepło rodzinne, wsparcie otoczenia, a także czynniki kulturowe, polityczno-społeczne czy demograficzne (Carr, 2009; Huppert, 2007; Myers, 2007; Trzebińska, 2008).

\section{Satysfakcja z życia w kontekście globalizacji i poszukiwania własnej tożsamości}

Subiektywny dobrostan może być rozpatrywany w różnych kontekstach. Szczególnie interesującą płaszczyzną kształtowania dobrostanu mogą być warunki makrospołeczne. Globalizacja może mieć znaczenie dla satysfakcji z życia, ponieważ tworzy te warunki. Jest ona przestrzenią życia jednostek, w której realizują swoje potrzeby, zdobywają lub traca zasoby i przechodzą kolejne etapy rozwoju. Socjologowie określają zjawisko globalizacji jako:

[...] proces oznaczający zacieśnienie stosunków i wzrost współzależności w skali świata [...] jako wypadkową procesów politycznych, gospodarczych, kulturowych i społecznych (Giddens, 2008, s. 74).

Wielu badaczy podkreśla, że globalizacja jest jedną z najważniejszych charakterystyk współczesnego świata. W kulturowo-informacyjnych ujęciach globalizacji podkreśla się, że współczesność to globalna kulturowa cyrkulacja, w której przemieszczają się „ludzie, mechanizmy, pieniądze, obrazy, idee" (Appadurai, 2005 , s. 58). Inni wskazują na upowszechnienie się kultury anglo-amerykańskiej, wraz z jej wartościami takimi jak: indywidualizm, prawa jednostki, wolność wyboru itp. (Arnett, 2002; Giddens, 2000). Ważnym atrybutem zglobalizowanej kultury jest konsumpcjonizm rozumiany jako specyficzny sposób życia (Ritzer, 2007). Wydaje się, że jedną z głównych ról współczesnego człowieka jest bycie konsumentem. W literaturze opisana jest strategia ,celowego postarzania produktu" (planned obsolescence), które polega na stosowaniu przez producentów takich ustawień fabrycznych, materiałów i oprogramowania, by produkty służyły krócej, niż pozwalają na to warunki technologiczne. W związku z krótszym okresem przydatności konsumenci są niejako zmuszeni do zakupu nowego produktu (The Economist, 2015). W opisach globalizacji zwraca się uwagę na jej nieuchronność, co wymusza na podmiocie przyjmowanie wobec niej określonych postaw - postaw wobec narzucanej przez nią tendencji do zmian (Erikson, 1997). 
Psychologów najbardziej interesuje wymiar informacyjny, tzn. dotyczący informacji ważnych dla formowania systemu wartości, tożsamości indywidualnej oraz innych zmiennych kluczowych w rozwoju osobowości (Erikson, 2004). Nie jest to jednak związek oczywisty i zawsze występujący, ponieważ nie wszystkie grupy społeczne lub wiekowe są podatne w takim samym stopniu na oddziaływania globalizacji (Ariely, 2012; Ruta, Camfield, Donaldson, 2007).

Badanie związków między procesami tożsamościowymi a subiektywnym dobrostanem znajduje uzasadnienie w koncepcji Erika Eriksona (2004), który przywiązuje szczególną wagę do komfortu psychospołecznego biorącego swe podstawy m.in. w korzystnym poradzeniu sobie z kryzysami rozwojowymi, z których zadanie formowania się indywidualnej tożsamości jest jednym z najważniejszych. Wyniki dotychczasowych badań (Luyckx, Soenens, Berzonsky, Smits, Goossens, Vansteenkiste, 2007; Luyckx, Schwartz, Berzonsky, Soenens, Vansteenkiste, Smits, Goossens, 2008) wskazują na występowanie dodatnich związków między procesami: podejmowaniem zaangażowania, identyfikacją ze zobowiązaniem, eksploracją w głąb a lepszym przystosowaniem społecznym i relacjami w rodzinie. Badania wskazują, że w grupie osób o wysokim nasileniu procesów poszukiwania i zaangażowania występuje mniej symptomów depresyjnych i zachowań lękowych (Luyckx i in., 2007). Poszukiwanie ruminacyjne wykazuje dodatni związek z wystąpieniem symptomów depresyjnych i obniżoną samooceną (Luyckx i in., 2008).

\section{Podstawy teoretyczne badań własnych}

W badaniach własnych odwołano się do Modelu Podwójnego Cyklu Formowania się Tożsamości (Luyckx, Goossens, Soenens, Beyers, Vansteenkiste, 2005), który jest rozwinięciem koncepcji formowania się tożsamości Jamesa Marcii (1966) wprowadzającej dwa procesy tożsamościowe: poszukiwanie i zaangażowanie. Według autorów tego modelu procesy tożsamościowe przebiegają w dwóch cyklach: formowania zobowiązania (składają się na niego procesy eksploracji wszerz i podejmowanie zobowiązania) oraz cyklu ewaluacji zobowiązania (eksploracja głęboka i identyfikacja ze zobowiązaniem). Pomiędzy cyklami znajduje się proces poszukiwania ruminacyjnego. W tym ujęciu tożsamość osobista formuje się w dwóch etapach.

W pierwszym (formowanie zobowiązania) następuje zbieranie informacji z różnych źródeł, odnoszących się do różnych alternatyw tożsamościowych. Podejmowanie zobowiązania to przyjęcie określonego kierunku działania i wynikających $\mathrm{z}$ niego wyborów w najważniejszych dziedzinach życia (np. planów na przyszłość). Decyzje podjęte podczas tego procesu nie mają jednak charakteru ostatecznego i mogą się zmienić pod wpływem odczuwanego niezadowolenia, niepewności lub nowych informacji. W etapie (cyklu) drugim, czyli ewaluacji zobowiązania występuje proces eksploracji w głąb, który można określić jako próbę oceny, szacowania, zastanawiania się nad tym, czy podjęte zaangażowanie jest zgodne $\mathrm{z}$ indywidualnymi preferencjami i możliwościami jednostki. Identyfikacja ze zobowiązaniem oznacza uznanie podjętych decyzji i kierunków działania za zgodne z osobistymi standardami i aspiracjami. Proces eksploracji ruminacyjnej jest definiowany jako fiksacja na procesie eksploracji. Polega na nieustającym rozważaniu kwestii tożsamościowych (często powiązanych z lękiem i niepokojem), co utrudnia podjęcie decyzji w kwestiach tożsamościowych (Luyckx i in., 2008).

W badaniach wykorzystano zmodyfikowany model formowania się tożsamości (Słowińska, Oleszkowicz, 2015). Autorki włączyły poszukiwanie ruminacyjne do obu cykli (poszukiwanie ruminacyjne szerokie i głębokie). Ponadto w przypadku procesów eksploracji wyodrębniły definicyjnie jej refleksyjny i ruminacyjny charakter. Rozróżnienia te znajdują uzasadnienie w koncepcji samoświadomości Paula D. Trapnella i Jennifer D. Campbell (1999). Refleksyjny charakter eksploracji wyraźnie łączy się z satysfakcją z życia, gdyż oparty jest na emocjach pozytywnych i pozwala na uniknięcie ciągłej autoanalizy i braku decyzji związanych z podjęciem zobowiązania. $Z$ kolei podjęcie zaangażowania (zobowiązania) Aleksandra Słowińska i Anna Oleszkowicz (2015) traktują 
jako kulminację pierwszego cyklu formowania tożsamości i warunek konieczny eksploracji w głąb, podkreślając jednocześnie jego tymczasowy charakter.

Druga z wykorzystanych koncepcji jest autorskim ujęciem Alicji Senejko i Zbigniewa Łosia $(2011$; 2014) - problematyki globalizacji. W literaturze podkreśla się znaczenie globalizacji jako zjawiska społeczno-kulturowego dla przebiegu rozwoju zarówno jednostki, jak i całych grup społecznych (w tym grup pokoleniowych). Szczególną rolę przypisuje się jej w procesach związanych z wkraczaniem w dorosłość, w kształtowaniu tożsamości indywidualnej czy w budowaniu wizji dotyczącej własnej przyszłości (Arnett, 2003; Łoś, Senejko, 2013; Oleszkowicz, Senejko, 2013). Metodologicznym atutem badań globalizacji przez psychologów jest skoncentrowanie dociekań nie na opisie zjawiska globalizacji, ale na jego percepcji przez podmiot.

Psychologicznym ujęciem problematyki globalizacji jest Model Postaw Wobec Globalizacji (Senejko, Łoś, 2011). Model opiera się na kilku założeniach. Pierwsze dotyczy sposobu doświadczania globalizacji przez osobę. Postawa wobec globalizacji w tym ujęciu znaczy tyle, co odpowiedź człowieka na zglobalizowaną rzeczywistość. Autorzy modelu zakładają, że jednostkowa koncepcja globalizacji jest wypadkową poznawczego i emocjonalnego stosunku osoby do jej przejawów. Postawy odnoszą się do istniejących i obecnie doświadczanych realiów, a nie do ich pożądanego obrazu. W tym ujęciu postawy wobec globalizacji charakteryzują się dynamiką i zmiennością, które wynikają bezpośrednio z transgresyjnej natury osoby (Kozielecki, 2001; Straś-Romanowska, 2005). Można wyróżnić trzy postawy wobec globalizacji (Senejko, Łoś, 2016): (1) postawę akceptującą: przejawiającą się otwartością na globalną rzeczywistość, gotowością do zmian, odkrywania i chętnego korzystania $z$ nowych, dostępnych możliwości; (2) postawę krytyczną: odznaczającą się opozycyjnością i brakiem aprobaty form dyskryminacji, stygmatyzacji, nadużyć i moralizatorstwa wynikających z ładu globalnego (Kim, Bhawuk, 2008); (3) postawę lękliwą: manifestującą się wrażliwością na za- grożenia związane z globalizacją, niepewnością co do możliwości radzenia sobie z wyzwaniami stawianymi przez ład globalny itp.

\section{Problem badawczy}

Grupą, która szczególnie dotkliwie może odczuwać skutki globalizacji w wymiarze tożsamościowym i zadowolenia z życia, są młodzi dorośli (Karaś, Cieciuch, 2015). W literaturze określa się tak osoby w wieku od 20-22 do 35-40 lat. Dolna granica jest związana z przyznaniem młodemu człowiekowi pewnych przywilejów oraz obowiązków, górną zaś wyznacza osiągnięcie stabilizacji życia rodzinnego i zawodowego (Gurba, 2016). W literaturze wskazuje się, że nastąpiło opóźnienie realizacji podejmowanych w tym okresie zadań rozwojowych i przedłużenie kształtowania tożsamości. Może być to związane z poziomem satysfakcji z życia, ponieważ osiągnięcie sukcesu w kryzysie kształtowania tożsamości jest wyznacznikiem kondycji psychospołecznej jednostki (Erikson, 2004). Jedną z przyczyn opóźnienia w osiągnięciu dojrzałej tożsamości jest eksploracja ruminacyjna (Luyckx i in., 2008). Ze względu na towarzyszące ruminacji poczucie niepewności własnej przyszłości oczekuje się negatywnego związku tego procesu z poziomem satysfakcji z życia. Podobny związek może wystąpić w przypadku refleksyjnej eksploracji szerokiej. Jej wyższy poziom w okresie wczesnej dorosłości koreluje z lękiem i niższym poczuciem bezpieczeństwa i raczej wskazuje na pewne opóźnienie w procesie kształtowania się tożsamości, co może mieć niekorzystny wpływ na zadowolenie z życia (Brzezińska, Piotrowski, Garbarek-Sawicka, Karowska, Muszyńska, 2010; Oleszkowicz, Koziorowska, 2019).

Z kolei podejmowanie ról społecznych wynikających z zadań rozwojowych dla tego wieku (co wiąże się z decyzją o zaangażowaniu) ma pozytywny związek z zadowoleniem z życia, np. poprzez zdolność do zawierania bliskich związków (Pilarska, Suchańska, 2015). Wykazano również związek satysfakcji z życia ze stopniem zadowolenia z tempa realizacji poszczególnych zadań rozwojowych, z wyższym poziomem ogólnego i kryterialnego poczucia dorosłości 
(Misztela, 2018) oraz faktem podejmowania zadań rozwojowych (Havighurst, 1972).

O ile możemy znaleźć dane, że pozytywne rozwiązanie dylematów tożsamościowych wiąże się dodatnio z satysfakcją z życia (Erikson, 2004; Havighurst, 1972), to dotychczasowe badania nie dają jednoznacznej odpowiedzi na pytanie o związek globalizacji z satysfakcją z życia (Kowalik, 2015). Jedne z najważniejszych badań nad psychologicznymi konsekwencjami globalizacji były skoncentrowane na wpływie globalizacji na percepcję społeczną oraz przekonania na temat przeszłości i przyszłości (Kashima, Shi, Tsuchiya, Kashima, Cheng, Chao, Shin, 2011). Postrzeganie zmian jako pozytywnych korelowało dodatnio z optymistycznym spojrzeniem na przyszłość, a doświadczenie zmian jako negatywnych korelowało dodatnio z przewidywaniami pesymistycznymi o przyszłości i wyższym wartościowaniem ładu społecznego obowiązującego przed pojawieniem się globalizacji. Wydaje się zatem, że wyodrębniona przez Senejko i Łosia postawa lękliwa, ze względu na towarzyszący jej niepokój co do możliwości poradzenia sobie z problemami współczesnego świata, może wiązać się ujemnie z poziomem satysfakcji z życia. Z kolei postawa akceptująca (otwartość na zmiany) wobec globalizacji prawdopodobnie będzie związana dodatnio $\mathrm{z}$ jej poziomem. Przewidywany związek postawy krytycznej wobec globalizacji z jakością życia jest trudny do określenia na podstawie wcześniejszych badań, a tym samym bardzo interesujący badawczo. Z jednej strony krytycyzm wobec globalizacji (opór przez wrogość, szczególna wrażliwość na dyskryminację i towarzyszące temu duże pobudzenie emocjonalne o znaku negatywnym) mogą obniżać nastrój i wiązać się negatywnie z poziomem dobrostanu (Derbis, 2007). Z drugiej strony postawa krytyczna może się realizować przez konstruktywną opozycyjność, racjonalne rozważanie argumentów za i przeciw globalizacji, co ze względu na mogące towarzyszyć tym procesom poczucie zrozumiałości (Antonovsky, 1995) jest związane pozytywnie z dobrostanem (Antonovsky, 1979; 1993).

Biorąc pod uwagę powyższe rozważania, podstawowym celem badań było ustalenie związków między postawami wobec globalizacji a satysfakcją z życia. Kolejnym celem było uzyskanie wiedzy na temat związków między procesami tożsamościowymi a poziomem satysfakcji z życia w grupie młodych dorosłych. Dodatkowo interesowało nas ustalenie ewentualnych związków między procesami tożsamościowymi i postawami wobec globalizacji, które jak dotąd są najsłabiej opisane w literaturze, oraz ustalenie pośredniczącej roli procesów tożsamościowych w relacji: postawy wobec globalizacji a satysfakcja z życia.

Odwołując się do wcześniej przeprowadzonych analiz teoretycznych, w pracy sformułowano następujące hipotezy badawcze:

- H1. Istnieje dodatni związek między postawą akceptującą wobec globalizacji a satysfakcją z życia.

- H2. Istnieje ujemny związek między postawą lękliwą wobec globalizacji a satysfakcją z życia.

- H3. Istnieje dodatni związek między procesami tożsamościowymi (refleksyjne poszukiwanie głębokie, identyfikacja ze zobowiązaniem i podjęcie zaangażowania) a satysfakcją z życia.

- H4. Istnieje ujemny związek między procesami tożsamościowymi (ruminacyjne poszukiwanie głębokie, ruminacyjne poszukiwanie szerokie i refleksyjnym poszukiwaniem szerokim) a satysfakcją z życia.

- H5. Istnieje dodatni związek między postawą lękliwą wobec globalizacji a procesami ruminacyjnego poszukiwania szerokiego i głębokiego.

- H6. Procesy tożsamościowe mediują związek między postawami wobec globalizacji a satysfakcją z życia.

\section{METODA}

\section{Osoby badane i przebieg badania}

Badanie prowadzone było na terenie południowo-zachodniej Polski, metodą papier-ołówek. Wzięło w nim udział 403 młodych dorosłych w wieku od 19. do 35. roku życia $(M=22,84$; 
$S D=2,81)$, w tym 219 kobiet $(54,3 \%)$ i 184 mężczyzn. W grupie badanej $91,56 \%$ badanych było poniżej 26. roku życia i posiadało status studenta studiów stacjonarnych lub niestacjonarnych. Odsetek badanych pracujących zarobkowo wyniósł 46,38\%. W momencie zbierania danych wszyscy uczestnicy ukończyli naukę w szkole średniej. Procedura badania polegała na rozdaniu kwestionariuszy w salach dydaktycznych oraz indywidualnie. Wypełnienie testów trwało średnio 20 minut. Badani zostali poinformowani o celu badania oraz jego anonimowym charakterze.

\section{Narzędzia}

W celu zbadania nasilenia procesów tożsamościowych wyróżnionych w ramach zmodyfikowanego Modelu Podwójnego Cyklu Formowania się Tożsamości zastosowano skróconą wersję Kwestionariusza Procesów Tożsamościowych (KTP-36) autorstwa Słowińskiej i Oleszkowicz (2015). Narzędzie umożliwia zbadanie sześciu procesów tożsamościowych: refleksyjnego poszukiwania szerokiego (alfa-Cronbacha .78), ruminacyjnego poszukiwania szerokiego (.82), podejmowania zaangażowania (.70), refleksyjnego poszukiwania głębokiego (.80), ruminacyjnego poszukiwania głębokiego (.82) oraz identyfikacji ze zobowiązaniem $(.70)^{2}$ odnoszących się do różnych domen życia (zawodowej, intymnej, światopoglądowej itp.). Zastosowana wersja składa się z 36 twierdzeń (po sześć na każdy proces), które osoba badana ocenia przy użyciu 4-stopniowej skali typu Likerta, od 1 (zdecydowanie mnie nie opisuje) do 4 (zdecydowanie mnie opisuje), np. Chętnie myślę o różnych zawodach, które mógłbym w przyszłości wykonywać (refleksyjna eksploracji wszerz), Mam watpliwości, jakimi wartościami chciałbym się kierować w swoim życiu (ruminacyjna eksploracja wszerz), Myślę, że wiem, z jakimi ludźmi chciałbym się zaprzyjaźnić (podejmowanie zaangażowania), Moje doświadczenia sprawiaja, że mam coraz większa jasność odnośnie do wartości i poglądów, którymi staram się kierować (refleksyjna eksploracja w głąb), Staram się być takim człowiekiem, jakim postanowitem być, choć czuję, że takie podejście do życia wcale mnie nie zadowala (ruminacyjna eksploracja w głąb), Gdy myślę o moim partnerze, mam pewność, że ten zwiazek daje mi to, czego potrzebuję (identyfikacja ze zobowiązaniem). Rozpiętość skal wyników surowych we wszystkich wymiarach tożsamościowych wynosi od 6 do 24 punktów. Im wyższy wynik, tym większe nasilenie danego procesu. Dla każdej osoby oblicza się sześć wskaźników (Słowińska, Oleszkowicz, 2015).

Kwestionariusz „Świat-Ja” (KŚJ) opracowany przez Alicję Senejko i Zbigniewa Łosia (Senejko, Łoś, 2011; Łoś, Senejko, 2013) służy do badania postaw wobec globalizacji. Składa się z 35 itemów. Format odpowiedzi jest czterostopniowy (tak, raczej tak, raczej nie, nie). Kwestionariusz zawiera trzy skale ${ }^{3}$ postaw: Akceptująca, Krytyczna, Lękliwa. Przykładowe twierdzenie ze skali postawy lękliwej: 13. Obawiam się, ze nie jestem dostatecznie przedsiębiorczy, aby odnieść sukces $w$ dzisiejszym świecie, ze skali postawy krytycznej: 15. Oburza mnie, gdy jakaś firma lub jakiś kraj przywłaszcza sobie prawo do zasobów naturalnych lub kultury, które powinny być wspólnym dorobkiem całej ludzkości, ze skali akceptującej: 27. Lubię widoczny wptyw egzotycznej kultury lub religii na zachowanie i sposób myślenia Polaków. Liczba punktów, jaką można uzyskać na poszczególnych skalach, wynosi: Akceptująca: 24 punkty, Krytyczna: 24 punkty, Lękliwa: 30 punktów. Rzetelność skal obliczona metodą alfa-Cronbacha na dużej próbie osób w różnym wieku $(N=1788$; wiek: $M=35,47 ; S D=16,57)$ wynosi .74 dla postawy lękliwej, .77 dla postawy krytycznej i .75 dla postawy akceptującej.

Skala Satysfakcji z Życia (SWLS) Dienera i współpracowników (1985) w adaptacji Zygfryda Juczyńskiego (2001) składa się z pięciu twierdzeń, odpowiedzi udziela się na siedmiostopniowej skali (1 - zupetnie się nie zgadzam; 7 - całkowicie się zgadzam). Służy do badania poznawczego aspektu zadowolenia z życia. Rzetelność skali wynosi $\alpha=.81$.

W prezentowanych badaniach rzetelność skal KPT-36 wyniosła $\alpha=.58-.70$, w przypadku KS-J $\alpha=.65-.71$, a rzetelność skali SWLS wyniosła $\alpha=.79$. 


\section{Wyniki}

Statystyki opisowe zostały przeprowadzone na całej grupie, ponieważ test t Studenta wykazał, że w zakresie wszystkich uwzględnio- nych zmiennych nie występują różnice międzypłciowe (na poziomie $p<.05$ ). Wyniki analiz pozwoliły ustalić, że rozkład jest zbliżony do normalnego - wartości współczynników skośności i kurtozy w przedziale od -1 do 1 .

Tabela 1. Statystyki opisowe dla badanych zmiennych

\begin{tabular}{|l|c|c|c|c|}
\hline \multicolumn{1}{|c|}{ Zmienna } & $\boldsymbol{M}$ & $\boldsymbol{S D}$ & Skośność & Kurtoza \\
\hline satysfakcja z życia & 22.52 & 5.08 & -.40 & -.14 \\
\hline refleksyjne poszukiwanie szerokie & 16.18 & 3.18 & -.04 & -.06 \\
\hline ruminacyjne poszukiwanie szerokie & 11.86 & 3.36 & .39 & -.46 \\
\hline podejmowanie zaangażowania & 17.92 & 2.87 & -.09 & .26 \\
\hline refleksyjne poszukiwanie głębokie & 17.72 & 3.01 & -.34 & -.13 \\
\hline ruminacyjne poszukiwanie głębokie & 13.28 & 3.76 & .29 & -.30 \\
\hline identyfikacja ze zobowiązaniem & 17.84 & 3.27 & -.16 & -.65 \\
\hline postawa akceptująca & 12.34 & 4.89 & .16 & -.52 \\
\hline postawa krytyczna & 14.83 & 3.93 & .08 & -.08 \\
\hline postawa lękliwa & 12.68 & 4.87 & .21 & .01 \\
\hline
\end{tabular}

W celu weryfikacji hipotez $\mathrm{H} 1-\mathrm{H} 6 \mathrm{w}$ pierwszej kolejności zastosowano współczynnik ko-

relacji Pearsona. Wyniki zostały przedstawione w tabeli 2.

Tabela 2. Współczynniki korelacji r-Pearsona dla satysfakcji z życia, procesów tożsamościowych i postaw wobec globalizacji

\begin{tabular}{|l|c|c|c|c|c|c|c|c|c|c|}
\hline Zmienna & $\mathbf{1 .}$ & $\mathbf{2 .}$ & $\mathbf{3 .}$ & $\mathbf{4 .}$ & $\mathbf{5 .}$ & $\mathbf{6 .}$ & $\mathbf{7 .}$ & $\mathbf{8 .}$ & $\mathbf{9 .}$ & $\mathbf{1 0 .}$ \\
\hline 1. satysfakcja z życia & & & & & & & & & & \\
\hline $\begin{array}{l}\text { 2. refleksyjne poszu- } \\
\text { kiwanie szerokie }\end{array}$ & $.14^{* *}$ & & & & & & & & & \\
\hline $\begin{array}{l}\text { 3. ruminacyjne po- } \\
\text { szukiwanie szerokie }\end{array}$ & $-.24^{* *}$ & $.16^{* *}$ & & & & & & & & \\
\hline $\begin{array}{l}\text { 4. podejmowanie } \\
\text { zaangażowania }\end{array}$ & $.26^{* *}$ & $.31^{* *}$ & $-.14^{* *}$ & & & & & & & \\
\hline $\begin{array}{l}\text { 5. refleksyjne poszu- } \\
\text { kiwanie głębokie }\end{array}$ & $.29^{* *}$ & $.35^{* *}$ & $-.28^{* *}$ & $.56^{* *}$ & & & & & & \\
\hline $\begin{array}{l}\text { 6. ruminacyjne po- } \\
\text { szukiwanie gębokie }\end{array}$ & $-.23^{* *}$ & .03 & $.59^{* *}$ & -.04 & $-.25^{* * *}$ & & & & & \\
\hline $\begin{array}{l}\text { 7. identyfikacja ze } \\
\text { zobowiązaniem }\end{array}$ & $.28^{* *}$ & $.11^{*}$ & $-.43^{* *}$ & $.37^{* *}$ & $.49^{* *}$ & $-.31^{* *}$ & & & & \\
\hline $\begin{array}{l}\text { 8. postawa } \\
\text { akceptująca }\end{array}$ & .02 & $.31^{* *}$ & .08 & $.12^{*}$ & $.12^{*}$ & -.06 & -.002 & & & \\
\hline 9. postawa krytyczna & -.09 & .06 & $.23^{* *}$ & .07 & .04 & $.23^{* *}$ & .03 & -.08 & & \\
\hline 10. postawa lękliwa & -.09 & $-.11^{*}$ & $.33^{* *}$ & $-.14^{* *}$ & $-.19^{* *}$ & $.47^{* *}$ & $-.19^{* *}$ & $-.20^{* *}$ & $.47^{* *}$ & \\
\hline
\end{tabular}

$* p<.05 ; * * p<.01$ 
Nie zaobserwowano istotnych związków dla relacji postawy wobec globalizacji - satysfakcja z życia. Tym samym nie zostały potwierdzone hipotezy H1 i H2.

Analiza korelacji pozwoliła ustalić, że satysfakcja z życia wchodzi w istotne związki ze wszystkimi procesami tożsamościowymi. Pozytywny związek wystąpił z procesami refleksyjnego poszukiwania szerokiego i głębokiego, podejmowania zaangażowania oraz z identyfikacją z zaangażowaniem. Siła tych związków jest na poziomie niskim (por. tabela 2). Przy czym najniższa i niewiele wyjaśniająca jest korelacja z procesem poszukiwania szerokiego (.14). Jednocześnie jej kierunek jest niezgodny z postawioną hipotezą. Tym samym, poza jednym wyjątkiem, zostały potwierdzone hipotezy H3 i H4.

Odnotowano również istotne korelacje między postawami wobec globalizacji a procesami tożsamościowymi. Zgodnie z hipotezą H5 potwierdziły się związki postawy lękliwej z ruminacyjnym poszukiwaniem szerokim i głębokim. Związki te są na poziomie umiarkowanym (.33, -.47). Ponadto uzyskano istotne statystycznie, choć na bardzo niskim poziomie, ujemne zależności między postawą lękliwą a pozostałymi (adaptacyjnymi) procesami formowania się tożsamości. Z kolei analiza korelacji między postawą akceptującą a refleksyjnym poszukiwaniem szerokim wykazała, że jest to związek dodatni, na poziomie .31 , co wskazuje na to, że im bardziej osoba jest nastawiona na zmiany i je akceptuje, tym większą przejawia aktywność związaną $\mathrm{z}$ analizą różnych alternatyw tożsamościowych.

W celu bardziej precyzyjnego określenia związków między uwzględnionymi zmiennymi w kolejnym kroku przeprowadzono modelowanie równań strukturalnych. Opierając się na rezultatach wcześniejszych badań oraz wynikach analizy korelacji skonstruowano model, w którym procesy tożsamościowe odgrywają rolę mediatorów relacji między postawami wobec globalizacji a satysfakcją z życia. Model estymowano metodą największej wiarygodności (por. ryc. 1).

Opracowany model jest bardzo dobrze dopasowany do danych $\left(\chi^{2}(17)=25,95 ; p=.08\right.$; $\mathrm{RMSEA}=.036 ; \mathrm{AGFI}=.96 ; \mathrm{CFI}=.99 ; \mathrm{SRMR}$ $=.03$ ). Postawy wobec globalizacji i procesy tożsamościowe pozwalają wspólnie wyjaśnić $12 \%$ zmienności poziomu satysfakcji z życia.

Bezpośrednimi predyktorami satysfakcji z życia są procesy cyklu ewaluacji zobowiązania: refleksyjne $(\beta=.19 ; p<.001)$ i ruminacyjne poszukiwanie głębokie $(\beta=-.14$; $p=.004)$ oraz identyfikacja ze zobowiązaniem $(\beta=.14 ; p=.008)$ (por. tabela 3 ). Postawy wobec globalizacji oraz procesy poszukiwania szerokiego są związane z satysfakcją z życia jedynie w sposób pośredni, przy czym znaczący efekt pośredni obserwujemy tylko w przypadku ruminacyjnego poszukiwania szerokiego (-.21) oraz postawy lękliwej (-.13; por. tabela 3$)$.

Tabela 3. Standaryzowane efekty bezpośrednie, pośrednie i ogólne dla związku postaw wobec globalizacji i procesów tożsamościowych z satysfakcją z życia

\begin{tabular}{|l|c|c|c|}
\hline \multirow{2}{*}{\multicolumn{1}{|c|}{ Zmienne }} & \multicolumn{3}{c|}{ Efekt } \\
\cline { 2 - 4 } & bezpośredni & pośredni & ogólny \\
\hline postawa akceptująca & - & -.002 & -.002 \\
\hline postawa krytyczna & - & .049 & .049 \\
\hline postawa lękliwa & - & -.127 & -.127 \\
\hline refleksyjne poszukiwanie szerokie & - & .097 & .097 \\
\hline ruminacyjne poszukiwanie szerokie & - & -.207 & -.207 \\
\hline refleksyjne poszukiwanie głębokie & .188 & .056 & .245 \\
\hline ruminacyjne poszukiwanie głębokie & -.140 & - & -.140 \\
\hline identyfikacja ze zobowiązaniem & .144 & - & .144 \\
\hline
\end{tabular}




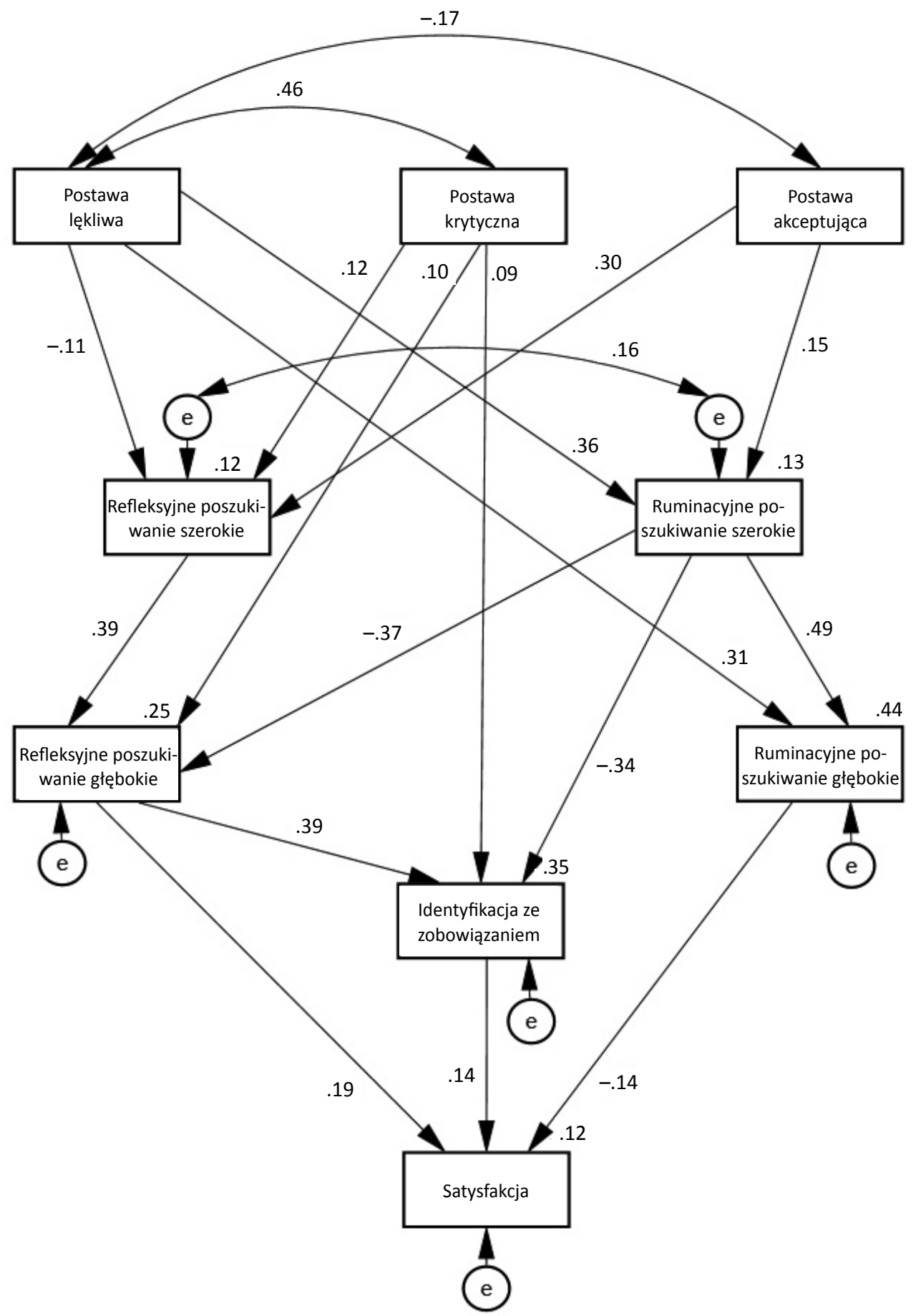

Ryc. 1. Model zależności pomiędzy postawami wobec globalizacji i satysfakcją z życia z procesami tożsamościowymi jako mediatorami 
Wszystkie postawy wobec globalizacji pozwalają jednak przewidzieć nasilenie procesów tożsamościowych. Postawa lękliwa wiąże się $\mathrm{z}$ wyższym nasileniem szerokiego $(\beta=.36 ; p<$ $.001)$ i głębokiego poszukiwania ruminacyjnego $(\beta=.31 ; p<.001)$ oraz z niższym nasileniem refleksyjnego poszukiwania szerokiego $(\beta=-.11$; $p=.049)$. Postawa akceptująca jest natomiast predyktorem wyższego nasilenia szerokiego $(\beta=.30 ; p<.001)$ i głębokiego poszukiwania refleksyjnego $(\beta=.15 ; p=.001)$. Postawa krytyczna również wiąże się z wyższym nasileniem adaptacyjnych procesów poszukiwania $(\beta=$ $.12 ; p=.02$ i $\beta=.10 ; p=.02-$ odpowiednio dla poszukiwania szerokiego i głębokiego) oraz z wyższym poziomem identyfikacji ze zobowiązaniem $(\beta=.09 ; p=.04)$.

Uzyskany model ścieżkowy wzbogacił naszą wiedzę na temat badanych zależności, dokumentując kierunki wpływu oraz rolę procesów tożsamościowych jako mediatorów relacji postawy wobec globalizacji a satysfakcji z życia.

\section{Dyskusja wyników}

Wyniki badań wskazują na brak bezpośredniego związku postaw wobec globalizacji z satysfakcją z życia. Jest to wynik ciekawy, ponieważ weryfikuje niektóre postulaty teoretyczne dotyczące charakteru tego związku. Stanisław Kowalik (2015) postuluje, że globalizacja może mieć negatywny wpływ na jakość naszego życia. Wskazuje on na zewnętrzny i przymusowy charakter zmian globalnych, które obniżają poczucie dobrostanu. Przeprowadzone badania są ważne, ponieważ wskazują, że związek globalizacji z satysfakcją z życia nie musi być prosty, a może być zapośredniczony przez inne zmienne psychologiczne, takie jak indywidualna tożsamość. Poszukiwanie wyjaśnienia, jak zglobalizowana rzeczywistość wpływa na satysfakcję z życia, jest wartościowe poznawczo, ponieważ dotychczas większość badań miała postać dociekań teoretycznych (Abdel-Hadi, 2012; Bhagvati, 2007) lub nie dotyczyła bezpośrednio satysfakcji, a tożsamości narodowej (Ariely, 2012) lub rozwoju człowieka (Arnett, 2011).

Związek postaw wobec globalizacji z procesami tożsamościowymi zachodzi, ale za- leżność ta jest związana z rodzajem postawy i treścią procesu tożsamościowego. Najsilniejszy związek zaobserwowano między postawą akceptującą wobec globalizacji i refleksyjnym poszukiwaniem szerokim. Zależność ta znajduje uzasadnienie w teorii, ponieważ w ujęciu Senejko i Łosia (2016) akceptacja wobec globalizacji przejawia się w otwartości na nowe doznania, gotowości do zmian, chęci odkrywania i korzystania z możliwości, poszukiwanie szerokie zaś jest przejawianiem podobnych zachowań w odniesieniu do tożsamości (Oleszkowicz, Senejko, 2013). Młody człowiek korzysta z możliwości, ale tylko pobieżnie, ponieważ żadnej nie poświęca dłużej uwagi. Towarzyszy temu aktywne poszukiwanie i analiza informacji dotyczących różnych alternatyw tożsamościowych, w które jednostka angażuje się przed podjęciem zobowiązań, wiążące się z otwartością, ciekawością poznawczą oraz odczuwaniem zadowolenia (Słowińska, Oleszkowicz, 2015). Wynik ten pokazuje, że poszukiwanie szerokie w grupie młodych dorosłych może być pod wpływem zarówno cech osobowości, np. lęku, jak i pod wpływem czynników kulturowych. Znajduje to wyraz w opisywanym przez Annę Brzezińską (2017) procesie opóźnienia vs odroczenia kształtowania tożsamości. Dla Brzezińskiej opóźnienie jest wyrazem doświadczenia zamętu tożsamościowego, co może wiązać się z nasiloną ruminacją. $Z$ kolei odroczenie oznacza dominację eksploracji nad podjęciem decyzji $\mathrm{i}$,utknięcie” w fazie moratorium.

Postawa lękliwa wobec globalizacji jest silnie związana z procesami poszukiwania ruminacyjnego (szerokim i głębokim). Manifestuje się ona wrażliwością na zagrożenia związane z globalizacją, niepewnością co do możliwości poradzenia sobie z nowym typem wyzwań, co w sferze procesów tożsamościowych jest związane z ruminacją szeroką, czyli uporczywym zaabsorbowaniem poszukiwaniami informacji na temat alternatyw tożsamościowych, czemu towarzyszy poczucie niepewności, intruzywne myśli oraz doświadczanie niepokoju i obniżonego nastroju. Postawa lękliwa jest związana także z poszukiwaniem ruminacyjnym głębokim, czyli uporczywym zaabsorbowaniem poszukiwaniem informacji dotyczących podjętych 
decyzji tożsamościowych, wiążące się powracającymi wątpliwościami, doświadczaniem niepokoju, niepewności, obniżonego nastroju oraz z poczuciem niekompetencji. Postawa lękliwa jest również związana ujemnym, słabym, ale istotnym związkiem z pozytywnymi procesami tożsamościowymi. Najsilniejszy ujemny związek wykazuje ta postawa $\mathrm{z}$ refleksyjnym poszukiwaniem głębokim, co może wskazywać, że lęk wobec globalizacji nie sprzyja dokonywaniu pogłębionej oceny podjętych zobowiązań w celu określenia stopnia ich zgodności z osobistymi celami i wartościami. Można przyjąć, że wyższe natężenie lęku globalizacyjnego hamuje procesy ewaluacji podjętych zobowiązań tożsamościowych. Postawa lękliwa jest związana ujemnie również z procesami podejmowania zobowiązania i identyfikacji z nim, co jest zbieżne z wynikami wcześniejszych badań dotyczących wymiarów kształtowania się tożsamości i ich podmiotowych korelatów (Brzezińska i in., 2010). Wyższy poziom lęku wobec globalizacji jest negatywnie związany z procesem poszukiwania szerokiego, co jest wynikiem ciekawym, ponieważ zazwyczaj lęk jako cecha koreluje dodatnio z tym typem poszukiwania (Brzezińska $\mathrm{i}$ in., 2010). Osoby lękowe boją się przede wszystkim wyborów i ostatecznego podjęcia zobowiązania. Etap poszukiwań może być dobrym pretekstem, „wymówką” dla wyjaśnienia opóźnienia w procesie formowania tożsamości. Trudno wskazać, na czym polega takie poszukiwanie u osób z wyższym poziomem lęku i czy nie jest to głównie poziom deklaracji. Z kolei postawa lękliwa ogranicza otwarcie na alternatywy, jakie daje globalna rzeczywistość, co jest faktem dość oczywistym, ponieważ takie osoby są mniej ufne.

Postawa krytyczna wobec globalizacji jest związana najsilniej z adaptacyjnymi procesami poszukiwania. Pozytywnie wiąże się z refleksyjnym poszukiwaniem szerokim i głębokim oraz identyfikacją ze zobowiązaniem. Może to oznaczać, że opozycyjność i brak aprobaty globalizacji powoduje $\mathrm{w}$ grupie badanej intensywne poszukiwanie na obu poziomach oraz włączenie zobowiązań w obręb najważniejszych celów. Jest to wynik korespondujący z założeniami teoretycznymi (Antonovsky, 1995), wskazuje, że postawa krytyczna może mieć konsekwencje pozytywne dla funkcjonowania. Jest więc czynnikiem zwiększającym nasze zrozumienie procesów globalizacji.

Związek procesów tożsamościowych z satysfakcją z życia jest zbieżny z dotychczasowymi wynikami badań (Pilarska, 2012; Berzonsky, 2003). Ukonstytuowanie się indywidualnej tożsamości jest wyzwaniem rozwojowym (Erikson, 2004). Terminowa realizacja zadań rozwojowych wiąże się z rozwiązaniem problemów specyficznych dla danego okresu życia. Pozytywne wyniki prowadzą do zadowolenia, poczucia bezpieczeństwa i sukcesu oraz dają podstawy do skutecznego radzenia sobie $\mathrm{z}$ kolejnymi wyzwaniami (Havighurst, 1972). Co ciekawe, w innych badaniach, w grupie adolescentów statusy tożsamości związane z osiągnięciem dojrzałej tożsamości korelowały ujemnie z jakością życia (Oleś, 2010). Różnicę można wytłumaczyć tym, że w okresie adolescencji procesy tożsamościowe powinny być zorientowane na eksplorację, a nie na identyfikację ze zobowiązaniem. Sytuacja odwrotna występuje w przypadku młodych dorosłych, którzy, aby efektywnie funkcjonować, powinni zarzucić procesy eksploracyjne na rzecz głębszych związków z rzeczywistością i rolami społecznymi - podjęciem i identyfikacją ze zobowiązaniem.

Warto podkreślić, że związek podjęcia zobowiązania z poziomem satysfakcji z życia nie jest związkiem prostym, lecz jest mediowany przez identyfikację ze zobowiązaniem (Karaś, Kłym, Wasilewska, Rusiak, Cieciuch, 2012). Luyckx we wcześniejszych badaniach wskazał, że podejmowanie zaangażowania oraz identyfikacja ze zobowiązaniem są pozytywnie związane $\mathrm{z}$ satysfakcją z życia (Luyckx $\mathrm{i}$ in., 2006; 2008). Cytowani polscy badacze stwierdzili, że pozytywny związek podjęcia zobowiązania z satysfakcją z życia znika po wprowadzeniu mediatora - identyfikacji ze zobowiązaniem. Zgodnie z wynikami badań Karaś i współpracowników (2012) podjęcie zobowiązania prowadzi do wyższej satysfakcji z życia, tylko jeśli następuje po nim identyfikacja ze zobowiązaniem. Podsumowując, samo podjęcie zobowiązania jest neutralne wobec satysfakcji z życia. Wyniki tych badań są zgodne 
z postulatami teoretycznym Luyckxa (Luyckx i in., 2006; 2008), gdzie identyfikacja następuje po podjęciu zobowiązania. Może być to pozytywnym predyktorem satysfakcji z życia, ponieważ identyfikacja ze zobowiązaniem jest stopniem przekonania jednostki o słuszności podjętych decyzji, jest związana z poczuciem bezpieczeństwa i przekonaniem o sprawczości (Karaś i in., 2012).

Zgodnie z wynikami wcześniejszych badań (Luyckx i in., 2008) procesy ruminacyjne ujemnie korelują z poziomem satysfakcji z życia. Może być to związane z tym, że zarówno ruminacyjne poszukiwanie głębokie, jak i szerokie stwarzają poczucie niepewności, braku bezpieczeństwa, niekompetencji oraz obniżony nastrój.

Podstawowym ograniczeniem prezentowanych badań jest zawężenie grupy badanej do jednego etapu rozwoju człowieka. Przyszłe badania mogłyby skupić się na związku postaw wobec globalizacji z funkcjonowaniem ludzi starszych, niebędących prawdopodobnie pod tak dużą pre- sją zmian globalnych, lub osób urodzonych po roku 2000, które są uważane za będące pod ich najsilniejszym wpływem. Takie badania mogłyby dać kolejne argumenty za twierdzeniem, że związek globalizacji z satysfakcją z życia nie jest prosty i nie zawsze zachodzi, co znajduje uzasadnienie w postulatach teoretycznych (Ariely, 2012) i w tych badaniach. Kolejnym ograniczeniem może być uproszczenie zmiennej zależnej do subiektywnego dobrostanu. Jest to rozwiązanie wygodne w procesie badawczym, ale dające bardzo wąski zakres wyników. Dalsze studia mogłyby dotyczyć związku postaw wobec globalizacji z jakością życia, konstruktem pełniejszym. Uwzględnienie, jak ład globalny jest związany ze specyficznymi składowymi jakości życia, np. ze sferą metafizyczną, zdrowotną, biologiczną, społeczną, teleologiczną, pozwoli zbudować model zależności uwzględniający więcej, aniżeli tylko poznawczy aspekt zadowolenia z życia.

\section{PRZYPISY}

$1 \quad$ Badania zostały sfinansowane ze środków uzyskanych w konkursie wewnętrznym Wydziału Nauk Historycznych i Pedagogicznych Uniwersytetu Wrocławskiego, na dofinansowanie projektów badawczych młodych naukowców i uczestników studiów doktoranckich. Temat: Procesy tożsamościowe i postawy wobec globalizacji a satysfakcja z życia młodych dorosłych, kierownik: mgr Arkadiusz M. Jasiński.

2 Rzetelność testu została obliczona dla grupy 340 osób, uczniów szkół ponadgimnazjalnych i studentów.

Skale postaw Krytycznej i Lękliwej są dość wysoko skorelowane (.50-.60), zwłaszcza w ostatnich latach (w latach 2011-2013 korelacja ta była wyraźnie niższa, .20-.30). Za utrzymaniem rozłączności skal postaw Krytycznej i Lękliwej przemawia wymóg trafności teoretycznej, gdyż znacznie różnią się one treścią itemów.

\section{BIBLIOGRAFIA}

Abdel-Hadi A. (2012), Culture, quality of life, globalization and beyond. Procedia. Social and Behavioral Sciences, 50, 11-19.

Antonovsky A. (1979), Health, stress and coping. San Francisco, CA: Jossey-Bass.

Antonovsky A. (1993), The structure and properties of the sense of coherence scale. Social Science\& Medicine, 36, 725-733.

Antonovsky A. (1995), Rozwiktanie tajemnicy zdrowia. Jak radzić sobie ze stresem i nie zachorować. Warszawa: Fundacja IPN.

Appadurai A. (2005), Nowoczesność bez granic. Kulturowe wymiary globalizacji. Kraków: TAiWPN Universitas.

Ariely G. (2012), Globalisation and the decline of national identity? An exploration across sixtythree countries. Nations and Nationalism, 18, 461-482. 
Arnett J.J. (2002), The psychology of globalization. American Psychologist, 57(10), 774-783.

Arnett J.J. (2003), The moral dimensions of globalization. American Psychologist, 58(10), 815-816.

Arnett J. (2011), Bridging universal and cultural perspective. A vision for developmental psychology in a global world. Child Development Psychology, 6, 98-104.

Berzonsky M. (2003), Identity style and well-being: Does commitment master? Identity: An International Journal of Theory and Research, 3, 131-142.

Bhagvati J. (2007), Why the critics of globalization are mistaken. The Economist, 155, 1-21.

Brzezińska A.I. (2017), Tożsamość u progu dorostości. Wizerunek uczniów szkót ponadgimnazjalnych. Poznań: Wydawnictwo Naukowe Wydziału Nauk Społecznych UAM.

Brzezińska A.I., Piotrowski K., Garbarek-Sawicka E., Karowska K., Muszyńska K. (2010), Wymiary tożsamościowe a ich podmiotowe i kontekstowe korelaty. Studia Psychologiczne, 49, 1, 81-93.

Carr A. (2009), Psychologia pozytywna. Nauka o szczęściu i ludzkich siłach. Poznań: Z-sk i Spółka Wydawnictwo.

Diener E., Emmons R.A., Larson R.J., Griffin S. (1985), The Satisfaction with Life Scale. Journal of Personality Assessment, 49, 71-75.

Diener E., Lucas R.E., Oishi S. (2002), Dobrostan psychiczny. Nauka o szczęściu i zadowoleniu z życia. W: J. Czapiński (red.), Psychologia pozytywna. Nauka o szczęściu, zdrowiu, sile i cnotach człowieka, 35-50. Warszawa: Wydawnictwo Naukowe PWN.

Derbis R. (2007), Poczucie jakości życia a zjawiska afektywne. W: S. Kowalik (red.), Społeczne konteksty jakości życia, 13-52. Bydgoszcz: Wydawnictwo Uczelniane WSG.

Erikson E.H. (1997), Dzieciństwo i społeczeństwo. Warszawa: Wydawnictwo Naukowe PWN.

Erikson E.H. (2004), Tożsamość a cykl życia. Poznań: Wydawnictwo Zysk i S-ka.

Giddens A. (2000), Runaway world. How Globalization Is Reshaping our Lives. New York: Routledge.

Giddens A. (2008), Socjologia. Warszawa: Wydawnictwo Naukowe PWN.

Gurba E. (2016), Wczesna dorosłość. W: J. Trempała (red.), Psychologia rozwoju człowieka. Podręcznik akademicki, 287-311. Warszawa: Wydawnictwo Naukowe PWN.

Havighurst R.J. (1972), Developmental tasks and education. New York: David McKay.

Huppert F.A. (2007), Psychologia pozytywna w ujęciu populacyjnym: znaczenie kampanii społecznych we wzmacnianiu dobrostanu i zapobieganiu zaburzeniom. W: P.A. Linley, S. Joseph (red.), Psychologia pozytywna w praktyce, 442-465. Warszawa: Wydawnictwo Naukowe PWN.

Juczyński Z. (2001), Narzędzia pomiaru w promocji zdrowia. Warszawa: Pracownia Testów Psychologicznych PTP.

Karaś D., Cieciuch J. (2015), Domenowe podejście do kształtowania tożsamości. Weryfikacja trójwymiarowego modelu w różnych sferach życia w grupie młodych dorosłych. Studia Psychologiczne, 53(3), 63-75.

Karaś D., Kłym M., Wasilewska Ż.M., Rusiak D., Cieciuch J. (2012), Wymiary tożsamości a satysfakcja z życia u studentów i pracujących. Studia Psychologica, 12(1), 25-45.

Kashima Y., Shi J., Tsuchiya K., Kashima E.S., Cheng S.Y.Y., Chao M.M., Shin S., (2011), Globalization and folk theory of social change: How globalization relates to societal perceptions about the past and future. Journal of Social Issues, 67(4), 696-715.

Kim Y.Y., Bhawuk D.P.S. (2008), Globalization and diversity. Contributions from intellectual research. International Journal of Intercultural Research, 32, 301-304.

Kowalik S. (2015), Uśpione społeczeństwo. Szkice z psychologii globalizacji. Warszawa: Wydawnictwo Sedno.

Kowalik S. (1995), Pomiar jakości życia - kontrowersje teoretyczne. W: A. Bańka, R. Derbis (red.), Pomiar i poczucie jakości życia u aktywnych zawodowo oraz bezrobotnych, 75-85. Poznań: PRINTB.

Kozielecki J. (2001), Psychotransgresjonizm. Warszawa: Wydawnictwo Akademickie Żak.

Ledzińska M. (2012), Młodzi dorośli w dobie globalizacji. Warszawa: Difin.

Ledzińska M. (2006), Globalizacja i transgresja. W: E. Aranowska, M. Goszczyńska (red.), Człowiek wobec wyzwań i dylematów wspótczesności, 172-188. Warszawa: Wydawnictwo Naukowe Scholar.

Luyckx K., Schwartz S.J., Berzonsky M., Soenens B., Vansteenkiste M., Smits I., Goossens L. (2008), Capturing ruminative exploration: extending the fourdimensional model of identity formation in late adolescence. Journal of Research in Personality, 42, 58-82.

Luyckx K., Soenens B., Berzonsky M., Smits I., Goossens L., Vansteenkiste M. (2007), Information-oriented identity processing, identity consolidation, and well-being: The moderating role of autonomy, self-reflection and self-rumination. Personality and Individual Differences, 43, 1099-1111. 
Luyckx K., Goossens L., Soenens B., Beyers W., Vansteenkiste M. (2005), Identity statuses based upon 4 rather than 2 identity dimensions: extending and refining Marcia's paradigm. Journal of youth and adolescence, 34(6), 605-618.

Łoś Z., Senejko A., (2013), Doświadczanie globalizacji diagnozowane Kwestionariuszem Świat-Ja a style tożsamości młodzieży. W: M. Straś-Romanowska (red.), Drogi rozwoju psychologii wrocławskiej, 267-292. Wrocław: Wydawnictwo Uniwersytetu Wrocławskiego.

Marcia J.E. (1966), Development and validation of ego-identity status. Journal of Personality and Social Psychology, 3(5), 551-558.

Misztela A. (2018), Realizacja zadań rozwojowych w okresie wczesnej dorosłości oraz jej psychospołeczne uwarunkowania i konsekwencje. Uniwersytet Wrocławski, Instytut Psychologii, nieopublikowana praca doktorska.

Myers D.G. (2007), Związki z ludźmi a dobre życie: szukanie równowagi między interesem jednostki i wspólnoty w polityce społecznej. W: P.A. Linley, S. Joseph, Psychologia pozytywna w praktyce, 442-465. Warszawa: Wydawnictwo Naukowe PWN.

Oleszkowicz A., Koziorowska K. (2019), Formowanie się tożsamości osobistej w okresie stającej się dorosłości, w kontekście poczucia bezpieczeństwa i gotowości do zmian. Polskie Forum Psychologiczne, 2 (w druku).

Oleszkowicz A., Senejko A. (2013), Psychologia dorastania. Zmiany rozwojowe w dobie globalizacji. Warszawa: Wydawnictwo Naukowe PWN.

Oleś M. (2010), Wymiary tożsamości a subiektywna jakość życia u młodzieży. Czasopismo Psychologiczne, $16(1), 61-76$.

Pilarska A. (2012), Ja i tożsamość a dobrostan psychiczny. Poznań: Wydawnictwo Naukowe Wydziału Nauk Społecznych UAM.

Pilarska A., Suchańska A. (2015), Procesy tożsamości i poczucie tożsamości: wzajemne powiązania oraz znaczenie dla zdolności do bliskości. Studia Psychologiczne, 53(3), 91-104.

Ritzer G. (2007), The Globalization of Nothing. Thousand Oaks, CA: Pine Forge Press.

Ruta D., Camfield L., Donaldson C. (2007), Sen and the art of quality of life maintenance: Towards a general theory of quality of life and its causation. The Journal of Socio-Economics, 36, 397-423.

Senejko A., Łoś Z. (2011), Style tożsamości a doświadczanie globalizacji przez adolescentów. Paper presented at the 20th Polish National Conference in Developmental Psychology Knowledge About Development in the Study of the Human Being; Institute of Psychology, Jagiellonian University, Developmental Psychology Section of the Polish Psychological Association, Cracow, PL, June 13-16, 2011.

Senejko A., Łoś Z. (2014), Style przetwarzania tożsamościowego a ustosunkowanie do globalizacji. Paper presented at the 23rd Psychological Colloquia of the Polish Academy of Sciences (PAN), Human Subjectivity in the Contemporary World; University of Wrocław, University of Social Sciences and Humanities (SWPS), Polish Academy of Sciences, Wrocław, June 16-18, 2014.

Senejko A., Łoś Z. (2016), Attitudes toward globalization and identity styles. Roczniki Psychologiczne/Annals of Psychology, XIX(2), 315-331. doi: 10.18290/rpsych.2016.19.2-4en.

Słowińska A., Oleszkowicz A. (2015), Kwestionariusz Procesów Tożsamościowych (KPT) - walidacja narzędzia. Studia Psychologiczne, 53(3), 9-18.

Straś-Romanowska M. (2005), Jakość życia w świetle założeń psychologii zorientowanej na osobę. Kolokwia Psychologiczne, 13, 261-274.

Świerżewska D. (2010), Satysfakcja z życia aktywnych i nieaktywnych osób po 60. roku życia. Psychologia Rozwojowa, 15(2), 89-99.

The Economist (2015). Planned obsolescence. www.economist.com [dostęp: 7.05.2019].

Trzebińska E. (2008), Psychologia pozytywna. Warszawa: Wydawnictwa Akademickie i Profesjonalne. 